\title{
Tyrnin versolaikkutaudin leviämisbiologia ja testaus tyrnin lisäysaineistosta
}

\author{
Anna-Liisa Fabritius ja Hilkka Koponen \\ Soveltavan biologian laitos, PL 27,00014 HELSINGIN YLIOPISTO, anna-liisa.fabritius@helsinki.fi, \\ hilkka.koponen@helsinki.fi
}

\section{Johdanto}

Tyrni (Hippophaë rhamnoides L.) on Suomessa Pohjanlahden rannikolla ja Ahvenanmaalla luonnonvaraisena kasvava marjakasvi, jota viljellään myös ammattimaisesti. Vuonna 2002 viljelijöitä oli 333 ja pinta-ala 189 ha, josta satoikäistä kasvustoa oli 83 hehtaaria (MMM:n tietopalvelukeskus; puutarhayritysrekisteri). Tyrnin viljelyala on lisääntynyt maassamme viime vuosina voimakkaasti. Innostusta viljelyyn ovat lisänneet tutkimustulokset tyrnin marjojen edullisista terveysvaikutuksista. Marjat sisältävät runsaasti erilaisia vitamiineja ja terveyden kannalta tärkeitä yhdisteitä. Varsinkin marjojen Cvitamiinipitoisuus on erittäin korkea (100-360 mg vitamiinia/100 g marjoja, Prokkola ja Karhu 2001). Tyrnin siemenet ja hedelmäliha sisältävät öljyä, jossa on runsaasti terveydelle edullisia rasvahappoja, rasvaliukoisia vitamiineja, karotenoideja ja flavonoideja (Heikkilä 1995, Häkkinen ym. 1999). Tyrniöljyllä on todettu olevan edullisia vaikutuksia etenkin atooppisen ihottuman, sydän- ja verisuonitautien hoidossa (Johansson 1999, Yang ym. 1999). Lisäksi tyrnin marjoista jalostetaan monia muita tuotteita kuten mehuja, hilloja, jäätelöä ja liköörejä (Prokkola ja Karhu 2001).

Lupaavalle tuotannolle on ilmennyt uusi uhka, tyrninversolaikkutauti, joka vioittaa tyrnin versoja. Suomesta ensimmäiset tiedot taudin esiintymisestä ovat vuodelta 1992 (Parikka 1993). Taudin oireina ovat versoihin silmujen ympärille ja sivuversojen haarautumiskohtiin ilmestyvät punaruskean kirjavat pyöreähköt laikut, jotka vanhemmiten tummuvat ja painuvat kuopalle. Vanhoissa versoissa sienen aiheuttama tauti ilmenee pyöreähköinä runkolaikkuina tai syvinä koroina. Kuoren halkeillessa laikun tai koron kohdalta taudinaiheuttajan tumma, kova itiömassa pursuaa esiin. Pahoin tartunnan saaneet versot yleensä kuolevat eivätkä enää tuota marjoja. Vaikka luonnonvarainen tyrni onkin melko kestävä tälle sienitaudille, viljelijöiden suosimat korkeasatoiset venäläiset lajikkeet ovat poikkeuksetta osoittautuneet erittäin taudinaroiksi (Parikka ja Karhu 1998, Prokkola 2003). Versolaikkutautia on löytynyt myös suomalaisista lajikkeista kuten 'Raisasta', jota on pidetty taudille kestävänä lajikkeena (Parikka ja Karhu 1998). Versolaikkutauti heikentää myös tyrnien talvehtimista (Parikka ym. 2001). Tällä hetkellä tyrninversolaikkutaudin torjumiseksi ei ole muuta keinoa kuin olla viljelemättä taudille arkoja runsassatoisia lajikkeita. Versolaikkutauti on merkittävä tyrnin viljelyn ongelma, mutta siitä tiedetään toistaiseksi varsin vähän.

Tyrninversolaikkutaudin aiheuttajana pidetään Stigmina-sukuun kuuluvaa sientä (Parikka ja Karhu 1998), vaikka Pseudomonas syringae-bakteeria ja Verticillium-sientä (Kennedy 1987) on myös epäilty taudinaiheuttajiksi (Wahlberg 1996). Venäjältä tunnetaan useita tyrnin versoihin laikkuja aiheuttavia sieniä kuten Camarops polyspermum, Pyerochaeta berberidis, Monochaetia ampelophila, Cytospora spp., Microdiplodia eleagni ja Coryneum eleagni (Parikka 1993).

Tämän tutkimuksen tavoitteena on selvittää tyrninversolaikkutaudin aiheuttaja, sekä kartoittaa taudin leviämiseen ja tartuntaan liittyviä tekijöitä. Koska taudinkestävät lajikkeet ovat paras keino versolaikkutaudin torjuntaan, tämän tutkimuksen tavoitteena on myös kehittää laboratoriomenetelmä, jonka avulla versolaikkutaudin kestävyyttä voidaan testata tyrnin lajikejalostuksen varhaisessa vaiheessa. Tutkimuksessa selvitetään myös, minkälaisia versolaikkutautia aiheuttavia isolaatteja tyrniviljelmillämme esiintyy. Versolaikkuisolaattien karakterisoimiseksi tutkimuksessa etsitään isolaatteja erottavia geenimerkkejä niiden perintöaineksesta, DNA:sta.

\section{Aineisto ja menetelmät}

Näytteitä $(224 \mathrm{kpl})$ kerättiin versolaikkutautisista viljellyistä tyrneistä Hirvensalmelta, Janakkalasta, Kankaanpäästä, Kauhajoelta, Kokemäeltä, Kokkolasta, Merikarvialta, Mikkelistä, Rantasalmelta, Ruukista, Sotkamosta ja Säräisniemeltä. Näytteitä otettiin myös kahdesta luonnonvaraisesta tyrnikasvustosta Merikarvialta ja Siikajoelta. Näytteet kerättiin keväällä ja alkukesällä sekä sairaista tyrnin versoista että maahan pudonneista lehdistä. Laboratoriossa näytteet pintasteriloitiin ja asetettiin kasvatusmaljoille, jotta näytteessä esiintyvät sienet voisivat kasvaa kasvualustaan tunnistamista varten. Sienistä valmistettiin puhdasviljelmät itävyys-, itiötuotto- ja lehtilaikkukokeisiin sekä patogeenisuustesteihin. 
Lehtilaikkukokeessa terveitä pintasteriloituja tyrnin lehtiä (Raisa- ja Botanicheskaja Ljubitelskajalajike sekä 050=laitoksen tyrninjalostusaineiston jälkeläinen) tartutettiin Stigmina- ja Lepteutypa-sienten itiöillä. Tartutetut lehdet pidettiin ravintoalustamaljoissa +5 ja +15 asteen lämpötiloissa 18 tunnin valojaksossa.

Stigmina- ja Lepteutypa-sienten itiöiden itämisen optimilämpötilan selvittämiseksi sienten itiöitä levitettiin ravintoalustamaljoille, jotka pidettiin $+5,+10,+15 \mathrm{ja}+20$ asteen lämpötiloissa 24 tuntia.

Patogeenisuustesteissä terveitä Raisa-tyrnin versoja tartutettiin Stigmina- ja Lepteutypa-sienten itiösuspensiolla. Tartutuksen jälkeen tyrnin taimet pidettiin $+5 \mathrm{ja}+10$ asteen lämpötiloissa.

Versolaikkutautia aiheuttavien isolaattien vertailussa tarkasteltiin sienen ribosomaalista RNA:ta koodaavien geenien välisiä ns. ITS-alueita (internal transcribed spacer regions). ITS-alueet monistettiin polymeraasiketjureaktiotekniikan (PCR) avulla käyttämällä universaaleja ITS1-ja ITS4 -alukkeita (White ym. 1990). Monistustuotteet sekvenssoitiin DNA:n emäshappojärjestyksen selvittämiseksi.

\section{Tulokset ja tulosten tarkastelu}

Kaikilta koepaikkakunnilta löytyi Stigmina-sientä ja useilta paikkakunnilta myös toista, Lepteutypa-nimistä sientä. Erityisen paljon Lepteutypa-sientä oli Ruukin ja Sotkamon näytteissä. Sekä Stigmina- että Lepteutypa-sieniä löytyi myös luonnonvaraisena kasvavista tyrneistä. Molemmat sienet esiintyivät samassa laikussa useita kertoja (14 kpl), mikä viittaa siihen, että kyseessä saattaa olla useamman sienen aiheuttama tauti. Koska Lepteutypa-sientä löytyi yksinään 36 tautinäytteestä osoittaa, että se todennäköisesti vioittaa tyrniä. Stigmina-sieni on aikaisemmin eristetty tyrniltä Suomessa ja sen on todettu aiheuttavan tyrnillä versolaikkua (Parikka 1998), mutta muita tietoja siitä tyrnin taudinaiheuttajana kirjallisuudessa ei ole. Lepteutypa-sieni on raportoitu tyrnin varresta Sveitsistä, Saksasta ja Ranskasta (Shoemaker ja Müller 1965) sekä tyrnin kuolleista oksista ja versoista Tanskassa (Munk 1966), mutta taudinaiheuttajaksi sitä ei mainita. Vaikka Stigmina- ja Lepteutypa-sieniä löytyi myös luonnonvaraisista tyrneistä, niissä versolaikkuoireet olivat selvästi lievempiä kuin viljellyissä tyrneissä. Tämän tutkimuksen mukaan Stigmina- ja Lepteutypasienet ovat hyvin yleisiä tyrnin versolaikuissa ja siten todennäköisiä versolaikun aiheuttajia. Näiden sienten merkitys versolaikkutaudin muodostumisessa selviää versotartutuskokeissa.

Taulukko1. Stigmina- ja Lepteutypa-sienten esiintyminen ( $\mathrm{kpl}$ ) viljellyissä ja luonnonvaraisissa tyrneissä vuonna 2003.

\begin{tabular}{lccc}
\hline Paikkakunta & Näytteiden & & \\
& lukumäärä & Stigmina & Lepteutypa \\
Hirvensalmi & 21 & 16 & 0 \\
Janakkala & 20 & 4 & 2 \\
Kankaanpää & 12 & 4 & 1 \\
Kauhajoki & 19 & 8 & 0 \\
Kokemäki & 14 & 11 & 6 \\
Kokkola & 12 & 3 & 0 \\
Merikarvia, viljelty & 16 & 10 & 6 \\
$\quad$ luonnonvarainen & 8 & 0 & 0 \\
Mikkeli & 29 & 29 & 2 \\
Rantasalmi & 10 & 8 & 8 \\
Ruukki & 14 & 8 & 1 \\
Siikajoki, luonnonvarainen & 13 & 5 & 20 \\
Sotkamo & 20 & 4 & 4 \\
Säräisniemi & 16 & 7 & 51 \\
Yhteensä & & 117 & \\
\hline
\end{tabular}

Lehtilaikkukoe osoitti, että Stigmina- ja Lepteutypa-sienet aiheuttavat lehtilaikkuja tyrnin lehtiin. Laikut ovat pyöreähköjä ja väriltään tummia, ja vähitellen lehti muuttuu kokonaan lähes mustaksi. Lajikkeiden välillä ei löytynyt suuria eroja, mutta Botanicheskaja Ljubitelskaja oli alttein kokeessa mukana olleista lajikkeista (Taulukko 2). Stigmina -sienen kuromien muodostus oli runsasta +5 lämpötilassa, mikä osoittaa, että se on sopeutunut alempaan lämpötilaan kuin Lepteutypa. Voidaankin olettaa, että Stigmina pystyy lisääntymään tyrnin lehdillä syksyllä ilmojen viilettyä sekä varhain keväällä ennen ilmojen lämpenemistä. Lepteutypa-sieni tarvitsee korkeampaa lämpötilaa $\left(15^{\circ} \mathrm{C}\right)$ kuromien muodostukseen, joten 
sen kuromien tuotanto keskittynee kasvukauden lämpimämpään ajankohtaan. Stigmina- ja Lepteutypasieniä ei mainita kirjallisuudessa lehtilaikkutautien aiheuttajaksi, mutta Stigmina-sienen aiheuttamia lehtilaikkuja löytyi Mikkelissä sijaitsevalta tyrniviljelmältä elokuussa 2003 ja vuonna 2002 lokakuussa Kokemäeltä.

Taulukko 2. Stigmina- (Mi28) ja Lepteutypa- (Ru4) sienten aiheuttamat oireet tyrnin lehdissä $+5{ }^{\circ} \mathrm{C}$ :ssa 28 päivän jälkeen tartutuksesta ja $+15^{\circ} \mathrm{C}$ :ssa 19 päivän jälkeen tartutuksesta (18 tuntia valoa, 6 tuntia pimeää). Oireasteikko: $0=$ ei oireita, $1=$ heikko laikku, $2=$ selvä keskikokoinen laikku, $3=$ iso laikku, $4=$ =koko lehti tummunut. Havainnot on tehty 10 lehdestä.

\begin{tabular}{|c|c|c|c|c|c|c|c|c|}
\hline \multirow{2}{*}{ Lajikkeet } & \multicolumn{2}{|c|}{$+5{ }^{\circ} \mathrm{C}$} & \multicolumn{5}{|c|}{$+15^{\circ} \mathrm{C}$} & \multirow[b]{2}{*}{$\begin{array}{l}\text { Botanicheskaja } \\
\text { Ljubitelskaja }\end{array}$} \\
\hline & Oireet & $050^{\mathrm{a}}$ & Raisa & $\begin{array}{l}\text { Botanicheskaja } \\
\text { Ljubitelskaja }\end{array}$ & Oireet & $050^{\mathrm{a}}$ & Raisa & \\
\hline \multicolumn{9}{|l|}{ Stigmina } \\
\hline \multirow{6}{*}{$\mathrm{Mi} 28$} & 0 & 0 & 1 & 1 & 0 & 0 & 1 & 0 \\
\hline & 1 & 0 & 1 & 1 & 1 & 0 & 1 & 0 \\
\hline & 2 & 1 & 2 & 0 & 2 & 0 & 1 & 0 \\
\hline & 3 & 4 & 4 & 1 & 3 & 0 & 1 & 2 \\
\hline & 4 & 5 & 2 & 7 & 4 & 10 & 6 & 8 \\
\hline & & $1 *$ & $4 *$ & $8^{*}$ & & $1 *$ & & \\
\hline \multicolumn{9}{|l|}{ Lepteutypa } \\
\hline \multirow[t]{6}{*}{ Ru4 } & 0 & 8 & 8 & 7 & 0 & 0 & 5 & 4 \\
\hline & 1 & 2 & 1 & 1 & 1 & 0 & 1 & 2 \\
\hline & 2 & 0 & 1 & 2 & 2 & 0 & 1 & 3 \\
\hline & 3 & 0 & 0 & 0 & 3 & 0 & 1 & 0 \\
\hline & 4 & 0 & 0 & 0 & 4 & 10 & 2 & 1 \\
\hline & & & & & & $2 *$ & $1 *$ & $1 *$ \\
\hline
\end{tabular}

${ }^{\mathrm{a}}$ Laitoksen tyrnijalostusaineiston jälkeläinen

*Kuromien muodostusta

Stigmina- ja Lepteutypa-sienten itiöiden itävyyskoe osoitti, että nämä sienet itävät hyvin jopa +5 asteen lämpötilassa ja voivat siten kasvaa keväällä ja syksyllä melko alhaisissa lämpötiloissa (Kuva $1)$.

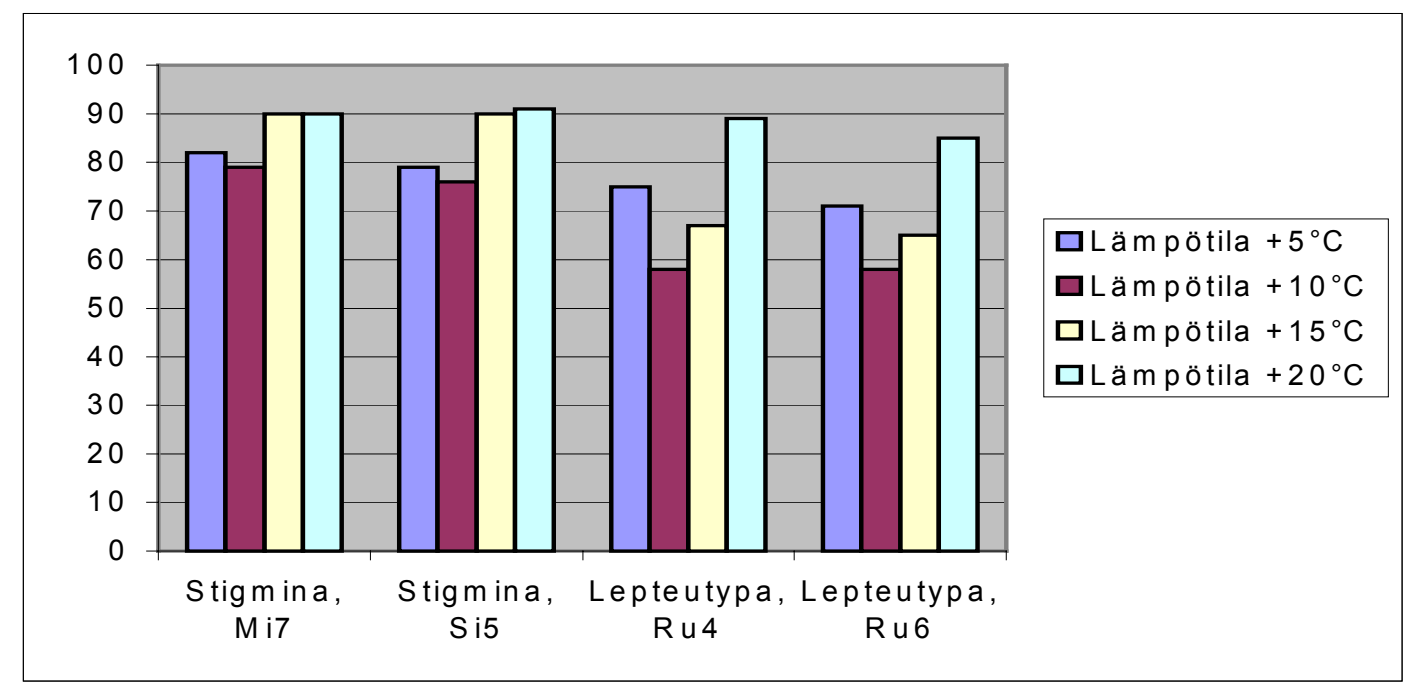

Kuva 1. Stigmina- (Mi7, Si5) ja Lepteutypa- (Ru4, Ru6) sienten itiöiden itävyys vesiagarilla pimeässä 24 tunnin jälkeen $+5,+10,+15 \mathrm{ja}+20$ asteen lämpötiloissa 
Noin 100 eri puolilta Suomea peräisin olevien Stigmina- ja Lepteutypa-isolaattien sekvenssointi osoitti, että eri lajien ITS-alueet eroavat suuresti toisistaan. Tätä sekvenssitietoa on tarkoitus hyödyntää PCR-pohjaisen menetelmän kehittämisessä versolaikkutaudin aiheuttajan tunnistamiseksi. Lajinsisäistä muuntelua esiintyi ITS-alueissa vain vähän. Eri Lepteutypa-isolaattien välillä löytyi vaihtelua n. $0,4 \%$.

\section{Johtopäätökset}

Tämän tutkimuksen tulokset viittaavat siihen, että tyrnin versolaikkutauti on usean sienen aiheuttama tautikompleksi, joiden eri osatekijöiden merkitystä taudin synnylle vielä selvitetään. Tutkimuksen tuloksia voidaan hyödyntää versolaikkutaudista vapaan tyrniaineiston tuotannossa. Kehitteillä on $\mathrm{mm}$. versolaikkutaudin kestävyystestausmenetelmä lajikejalostusta varten sekä taimiaineiston piilevien infektioiden paljastamiseen soveltuva PCR-pohjainen testi.

\section{Kiitokset}

Tutkimusta ovat rahoittaneet Suomen Kulttuurirahasto ja Oiva Kuusisto -säätiö.

\section{Kirjallisuus}

Heikkilä, M. 1995. Tyrni luonnonvaraisena ja viljelykasvina. Kirjallisuusselvitys. Satakuntaliitto. Sarja A: 227 , $53 \mathrm{~s}$.

Häkkinen, S., Heinonen, M., Kärenlampi, S., Mykkänen, H., Ruuskanen, J. \& Törrönen, R. 1999. Screening of selected flavonoids and phenolic acids in 19 berries. Food Res. Int. 32: 345-353.

Johansson, A. 1999. Availability of seed oil from Finnish berries with special reference to compositional, geographical and nutritional aspects. Academic dissertation on Food Chemistry. University of Turku. ISBN 952-911003-0.

Kennedy, D.M. 1987. Verticillium wilt of sea buckthorn (Hippophaë rhamnoides). Plant Pathology 36: 420-422. Munk, A. 1957. Danish Pyrenomycetes. A preliminary Flora. Dansk Botanisk Arkiv 17 (1):491 s.

Parikka, P. 1993. Versolaikku vioittaa tyrniä. Kasvinsuojelulehti 4/1993:100-102.

Parikka, P. \& Karhu, S. 1998. Stem canker on sea buckthorn (Hippophaë rhamnoides L.) in Finland. Teoksessa: $7^{\text {th }}$ International Congress of Plant Pathology, Edinburg 9.-16.8.1998. Posteriesitelmä, tiivistelmät, vol. 3.S.3. 7.51. Parikka, P. \& Karhu, S. 1999. Versolaikku vaivaa tyrniä. Puutarha \& Kauppa 1/1999:8.

Parikka, P. Tuovinen, T. \& Ruuttunen, P. 2001. Marjakasvien kasvinsuojelu. Puutarha \& Kauppa 7: 19-31.

Prokkola, S. 2003. Reliability of Russian sea buckthorn cultivars in North Ostrobothnia, Finland. Acta Horticulturae 626: 389-395.

Prokkola, S. \& Lehto, M. 2001. Tyrnin lajiketestaus ja jalostus. - Teoksessa: Prokkola, S. \& Lehto, M. (toim.), Pohjoisen Laatumarjat - Mansikka, Tyrni, Mesimarja, Jalomaarain: 46-66. 101 s. Pohjoisen -laatumarjat -hanke, MTT, Pohjois-Pohjanmaan tutkimusasema. Ruukki. ISBN 951-729-617-7.

Shoemaker, R.A. \& Müller, E. 1965. Types of the pyrenomycete genera Hymenopleella and Lepteutypa. Canadian Journal of Botany 43: 1457-1460.

Wahlberg, G. 1996. Havtorn - en nygammal bärbuske för fritidsodlingen. Fakta. Trädgård - Fritid 1999/56. 4 s. Yang, B., Kalimo, K.O., Mattila, L.M., Kallio, S.E., Katajisto, J.K., Peltola, O. J. \& Kallio, H.P. 1999. Effects of dietary supplementation with sea buckthorn (Hippophaë rhamnoides) seed and pulp oils on atopic dermatitis. J. Nutr. Biochem. 10: 622-630. 